American Journal of Economics and Business Administration 3 (3): 439-443, 2011

ISSN 1945-5488

(C) 2011 Science Publications

\title{
Knowledge Management Capabilities Rubrics
}

\author{
Azizah bt Abdul Rahman and Sara Hassani \\ Department of Computer Science and Information System, \\ University Technology Malaysia, 81310 Skudai, JOHOR, Malaysia
}

\begin{abstract}
Problem statement: Recently researchers discerned the vitality and importance of Knowledge Management Capabilities (KMC) evaluation in organizations. In fact evaluation of KMC helps to prevent failure in Knowledge Management (KM) projects. Approach: One of the most popular methods in the phase of evaluating KMC is Fuzzy method which evaluates seven attributes of KMC. Fuzzy needs KM experts to give their opinion about these attributes as input data. However in some organizations these experts are not available. Results: Therefore in this study a rubric matrix is developed as an assessment tool with ordered rank (very high, medium and very low) of descriptive characteristics of criteria (seven attributes) that organizations wish to evaluate. Conclusion: This rubric is applicable for members of an organization which are not familiar completely with KMC and also will be maintained by analyzing and surveying many different researches.
\end{abstract}

Key words: Knowledge Management Capabilities (KMC), knowledge management infrastructure, knowledge management processes, rubric matrix

\section{INTRODUCTION}

Rubric matrix is a clear set of criteria used for assessing a particular type of work or performance. A rubric also includes levels of potential achievement for each criterion. Using rubric has many advantages in this area such as: organizations can use rubric as a tool to improve their weaknesses; experts have explicit guidelines about how to judge about attributes; clarifying each attributes; easy and also exact evaluation and so on. Because of importance of KM, many organizations spend pervasive effort on $\mathrm{KM}$ projects. But many researchers indicated that many KM projects have failed. Investigating on these projects is for acquiring many goals and expectations, thus reasons for project's failure are so controversial. Don't be familiar with the status of organization's knowledge and also preconditions (capabilities) that they are very essential for KM efforts are reasons for failure of KM projects. Another reason of KM projects failure could be the lacking of knowledge audit ("The K-Audit is a discovery, verification and validation tool, providing fact-finding, analysis, interpretation, and reports. It includes a study of corporate information and knowledge policies and practices, of its information and knowledge structure and flow") for any KM plans and projects (Hylton, 2002).

Knowledge management capability means the condition and ability which individuals have within the area of knowledge management domain in knowledge activity system (Baimin et al., 2008). While many different meaning of $\mathrm{KMC}$ has been presented, there are some definitions that concentrate on KMC infrastructure. Organization's KMC infrastructure is defined as its ability to develop KM-based resources (KM and resource based here is defined as technical $\mathrm{KM}$ resource and social KM resource) by combination with other resources and capabilities (Chuang, 2004). On the other hand, focus of definitions is on KMC process. KMC consists of three processes: knowledge acquisition, knowledge dissemination and the last one use or responsiveness to knowledge (Darroch, 2003). $\mathrm{KM}$ is basically a human social process. It is a particular process, called knowledge processing, involving the production, evaluation, integration and control of how knowledge is created and used in organizations (Cavaleri, 2004; Kimber et al., 2007; Wei, 2008; Hitt et al., 2000; Jabar et al., 2010; Niess, 2005; Morrison and Sheng, 1992; Nonaka. and Takeuchi, 1995; Sher and Lee, 2004; Zhang et al., 2008).

In terms of some researchers' opinion, knowledge management should be defined as a combination of knowledge management process and knowledge management infrastructure. In this perspective $\mathrm{KMC}$ is expressed as $\mathrm{KM}$ infrastructure: technology, structure and culture and KM process: acquisition, conversion, application and protection (Gold et al., 2001).

Corresponding Author: Azizah bt Abdul Rahman, Department of Computer Science and Information System,

University Technology Malaysia, 81310 Skudai, JOHOR, Malaysia 
Am. J. of Economics and Business Administration 3 (3): 439-443 2011

Table 1: Rubric matrix of technology

\begin{tabular}{|c|c|c|c|}
\hline & Very high & Medium & Very low \\
\hline \multirow[t]{4}{*}{ Technology } & $\begin{array}{l}\text { Organization has technology which can deliver } \\
\text { relevant(requested knowledge by users) \& timely } \\
\text { (response to organization's members within a short } \\
\text { time) knowledge provision(e.g. email \& hand phone) } \\
\text { Organization has technologies which allow the firm to } \\
\text { track knowledge about its customers, partners, } \\
\text { employees or suppliers }\end{array}$ & $\begin{array}{l}\text { Members in organization could utilize } \\
\text { resources of relevant knowledge but not } \\
\text { anywhere or any time(e.g. there is Internet } \\
\text { but it isn't wireless Internet in that organization) } \\
\text { Technology help tracking knowledge about } \\
\text { organization's customers, partners, employees or } \\
\text { suppliers but it isn't advanced technology so } \\
\text { sometimes organization can't find related } \\
\text { knowledge timely }\end{array}$ & $\begin{array}{l}\text { The efficiency of knowledge utilization } \\
\text { and timeliness in delivering relevant } \\
\text { knowledge is not the property of } \\
\text { technology in organization } \\
\text { Information about organization's } \\
\text { customer, employee or suppliers isn't } \\
\text { followed by technology tools }\end{array}$ \\
\hline & $\begin{array}{l}\text { Organization has Collaboration technology that } \\
\text { allows a rich expression and discussion of ideas } \\
\text { proposals (e.g. Multimedia distribution } \\
\text { /service at universities) }\end{array}$ & $\begin{array}{l}\text { Members who are using collaboration technology } \\
\text { don't share their all resources and knowledge or } \\
\text { Sometimes collaboration technology isn't very new }\end{array}$ & $\begin{array}{l}\text { Because of lack of collaboration } \\
\text { technology members' requirements to } \\
\text { share and collaborate their knowledge } \\
\text { and resources is become very difficult }\end{array}$ \\
\hline & $\begin{array}{l}\text { Organization has technology which enable it to have } \\
\text { better representation of knowledge (e.g. Multimedia } \\
\text { distribution service in the universities) }\end{array}$ & $\begin{array}{l}\text { For representation of knowledge, organization uses } \\
\text { technology(e.g. video projector system in } \\
\text { universities) but as mentioned in very high level } \\
\text { technology in this level isn't newest one }\end{array}$ & $\begin{array}{l}\text { Representation of knowledge is done } \\
\text { without any technology }\end{array}$ \\
\hline & $\begin{array}{l}\text { Organization has technology which support the } \\
\text { efficient storage and retrieval of codified knowledge }\end{array}$ & $\begin{array}{l}\text { Storage and retrieval of codified knowledge is } \\
\text { supported by technology but it isn't advanced } \\
\text { technology and also sometimes a little bit } \\
\text { activities is done by hand }\end{array}$ & $\begin{array}{l}\text { Storage and retrieval of codified } \\
\text { knowledge is paper-based }\end{array}$ \\
\hline
\end{tabular}
(2010)

Indeed, knowing the status of firm's KMC is very important to do KM projects successfully. So, before starting any plan for KM, capabilities should be evaluated. There are many ways to evaluate KMC, such as scoring tool, fuzzy linguistic method, and Grey method and so on. In fuzzy method, opinions of experts are as input data. The problem arises when none of members of an organization are familiar with attributes of KMC. Due to this problem, in this study a rubric matrix is introduced for attributes of $\mathrm{KMC}$ in fuzzy linguistic method (Fan et al., 2008). To evaluate KMC of an organization by fuzzy method, after choosing a number of members, not necessarily expert, this rubric matrix helps members to give their opinion about each attributes more precisely. Then opinions will be input data for fuzzy method.

This study is organized as follows. In section 2, we present how the rubric matrix was developed. The result which is the rubric matrix for seven attributes is shown in section3.

Developing the rubric matrix: In this study, an influential evaluation tool -rubric- is developed both as an assessment tool and as guide. Rubric also makes decisions easier and more consistent.

Preparing of rubric back to the research that have done by Wei et al. (2009) for evaluating knowledge management capability of organizations by fuzzy linguistic method. In this research it is needed to choose several experts to give their opinions about level of seven attributes technology, structure, culture (infrastructure capability) and acquisition, conversion, application, protection (process capability). Since all respondents in an organization are not expert of
Knowledge management and they are not knowledgeable about attributes; this rubric explains each of the attributes which can help them to answer about attributes' level very precisely. Each attribute consists of several elements. Criteria for the rate of attributes' elements are in terms of very high, medium and very low. Very high and very low determine the best and worst status of attributes in the organization.

By analyzing and surveying many different researches that have done on these attributes and also by interviewing with experts in different fields of KM, this rubric matrix was developed. There are widespread researches on the field of each attributes. And also we can see many surveys about characteristics of these attributes. For example trust which is one of the elements of culture, is analyzed precisely under different topics such as: trust and management and knowledge sharing.

In academic area, there are many researchers which their research interests are about attributes and also their characteristics. Some expert is chosen to interview with them to clarify levels of rubric matrix and complete elements of attributes.

\section{RESULTS}

As mentioned in section 2, this rubric matrix was achieved by analyzing literature review and interviewing with experts of knowledge in faculty of computer science and information technology. About 30 lecturers were chosen which their main research interests relate to one of the attributes of KMC. Rubric matrix is shown in Table 1-6. 
Am. J. of Economics and Business Administration 3 (3): 439-443 2011

Table 2: Rubric matrix of structure

\begin{tabular}{|c|c|c|c|}
\hline & Very high & Medium & Very low \\
\hline \multirow[t]{3}{*}{$\begin{array}{l}\text { Organizational } \\
\text { structure }\end{array}$} & $\begin{array}{l}\text { Organizational structure is designed for } \\
\text { flexibility so that it encourage sharing \& } \\
\text { collaboration very well across boundaries } \\
\text { within the organization }\end{array}$ & $\begin{array}{l}\text { Conversation and discussion which is the first } \\
\text { step toward effective collaboration and effective } \\
\text { sharing of knowledge happens irregularly or } \\
\text { organization }\end{array}$ & $\begin{array}{l}\text { Organizational structure has the sometimes } \\
\text { isn't between all members of unintended } \\
\text { consequence of inhibiting collaboration } \\
\text { and sharing of knowledge across internal } \\
\text { organizational boundaries }\end{array}$ \\
\hline & $\begin{array}{l}\text { An organization's structure can determine } \\
\text { the channels from which knowledge is } \\
\text { accessed and how it flows }\end{array}$ & $\begin{array}{l}\text { Channels is determined by organization but } \\
\text { sometimes happen for members that channels } \\
\text { aren't enough or maybe they don't know kind } \\
\text { of knowledge or its flow }\end{array}$ & $\begin{array}{l}\text { Channels from which knowledge is } \\
\text { accessed and how it flows isn't determined } \\
\text { by organization }\end{array}$ \\
\hline & $\begin{array}{l}\text { System of organization should be structured } \\
\text { so that workers are motivated \& rewarded } \\
\text { for taking the time to generate new } \\
\text { knowledge, share their knowledge }\end{array}$ & $\begin{array}{l}\text { Motivation and reward exist within organization } \\
\text { for sharing and generating knowledge but rewards } \\
\text { are very limited and motivation isn't enough }\end{array}$ & $\begin{array}{l}\text { Knowledge workers don't motivate and } \\
\text { take rewards by organization to generate } \\
\text { and share new knowledge }\end{array}$ \\
\hline
\end{tabular}

Source: Chuang (2004) Gold et al. (2001) and Fan et al. (2008)

Table 3: Rubric matrix of culture

\begin{tabular}{llll}
\hline Very high & Medium & Very low \\
\hline Culture & $\begin{array}{l}\text { Culture is the most important view of } \\
\text { organization toward its goal as well as } \\
\text { the management type and methods }\end{array}$ & $\begin{array}{l}\text { Culture is important view of organization } \\
\text { toward its goal }\end{array}$ & $\begin{array}{l}\text { Culture doesn't have any role to } \\
\text { achieve goals }\end{array}$ \\
\end{tabular}
and methods

A climate of openness, trust and respectful amongst organization members is the basic condition that allows tacit knowledge to be created, shared and used (e.g., members collaborate with each other in confident environment)

Type of interaction and supporting collaboration in organization enable individuals, knowledge workers, teams and communities to make better decision faster and to create new ideas

Organization has sharing-oriented culture

(e.g. members share their knowledge easily)

Organization has innovation-oriented culture

Organization engender a sense of involvement (responsibility) and contribution among employees

Ethic such as openness, trust and so on are important amongst some organization members but not all of them

Sometimes members don't collaborate and share their talent and ongoing experience into organizational assets voluntarily and they need Managers stimulate them

Members share their knowledge and experiences but not all things that must be shared

Being innovative and creative support by organizations but not in all fields Employee has a sense of responsibility but organization doesn't engender them a lot
Openness, trust and respectful are not value for the member of organization

Source: Gold et al. (2001) and Wei (2008)

Table 4: Rubric matrix of acquisition and conversion

\begin{tabular}{|c|c|c|c|}
\hline & Very high & Medium & Very low \\
\hline \multirow[t]{3}{*}{ Acquisition } & $\begin{array}{l}\text { Members of organization make full use of } \\
\text { existing knowledge in organization to } \\
\text { acquire new knowledge } \\
\text { Organization uses newest techniques to } \\
\text { acquire knowledge such as data mining } \\
\text { (Data mining is the process of } \\
\text { extracting patterns from data.) }\end{array}$ & $\begin{array}{l}\text { Members of organization can't find existing } \\
\text { knowledge on time because the knowledge within } \\
\text { organization is not integrated and recorded completely } \\
\text { Organization is not following newest } \\
\text { techniques to acquire knowledge and the } \\
\text { techniques which are using aren't always new }\end{array}$ & $\begin{array}{l}\text { Knowledge workers and members will } \\
\text { faced with problems from lack of } \\
\text { knowledge distribution within organization } \\
\text { Members of organization don't use any } \\
\text { techniques to acquire knowledge OR maybe } \\
\text { the techniques which are using are the oldest one }\end{array}$ \\
\hline & $\begin{array}{l}\text { Members in organization have innovation } \\
\text { (as one aspect of acquisition), to create } \\
\text { new knowledge from the application of } \\
\text { existing knowledge }\end{array}$ & $\begin{array}{l}\text { Members of organization have irregularly } \\
\text { innovative activities }\end{array}$ & $\begin{array}{l}\text { Innovation to generate new ideas is not done by } \\
\text { members of organization }\end{array}$ \\
\hline & $\begin{array}{l}\text { It is important for an organization to } \\
\text { manage and identify which kind of } \\
\text { knowledge whether the organization need } \\
\text { (e.g., top managers look at outside } \\
\text { environment and their need and identify } \\
\text { what kind of knowledge organization } \\
\text { need to produce for outside environment) }\end{array}$ & $\begin{array}{l}\text { Assessment and management of kind of knowledge } \\
\text { which an organization needs to create will do within } \\
\text { organization but they are not on time or maybe } \\
\text { assessment and management are not parallel }\end{array}$ & $\begin{array}{l}\text { Organization doesn't know even which kind of } \\
\text { knowledge the organization needs }\end{array}$ \\
\hline Conversion & $\begin{array}{l}\text { Knowledge conversion must be interaction } \\
\text { between tacit and explicit knowledge AND } \\
\text { Tacit knowledge and explicit knowledge are } \\
\text { not separate and also complete each other. } \\
\text { They interchange to each other in the } \\
\text { innovative activities of human beings }\end{array}$ & $\begin{array}{l}\text { There is interaction between tacit and explicit and } \\
\text { also interchange to each other but not all times in } \\
\text { order of spiral of knowledge conversion }\end{array}$ & $\begin{array}{l}\text { Interaction between tacit and explicit very rarely } \\
\text { happens within organization. Members don't } \\
\text { follow order of spiral of knowledge } \\
\text { conversion at all }\end{array}$ \\
\hline
\end{tabular}


Am. J. of Economics and Business Administration 3 (3): 439-443 2011

Table 4: Continue

\begin{tabular}{|c|c|c|c|}
\hline & $\begin{array}{l}\text { Two or more members in organization } \\
\text { interact, and tacit knowledge is expressed } \\
\text { in a social way and passed from human } \\
\text { to human (tacit to tacit) }\end{array}$ & $\begin{array}{l}\text { Contact of members cause tacit to tacit but these } \\
\text { contacts are not extensive to convert all } \\
\text { tacit knowledge to tacit }\end{array}$ & $\begin{array}{l}\text { Tacit to tacit doesn't happen because of not } \\
\text { having extensive contact, trust and not } \\
\text { sharing of knowledge }\end{array}$ \\
\hline & $\begin{array}{l}\text { Members in organization captures tacit } \\
\text { knowledge by writing it down or capturing it } \\
\text { on computer (digitizing/codification) } \\
\text { (tacit to explicit) }\end{array}$ & $\begin{array}{l}\text { All tacit knowledge can't be captured to explicate } \\
\text { or sometimes members don't know how to convert } \\
\text { tacit to explicit }\end{array}$ & $\begin{array}{l}\text { Organization has failure to exploit tacit } \\
\text { knowledge AND Tacit improperly explicate }\end{array}$ \\
\hline & $\begin{array}{l}\text { In organization, Multiple sources of external } \\
\text { knowledge are brought together within a new } \\
\text { context, like researching multiple sources, } \\
\text { or when computers reference different } \\
\text { data sources (explicit to explicit) }\end{array}$ & $\begin{array}{l}\text { Explicit to explicit happens within organization but } \\
\text { Sometimes explicit knowledge is not enough for } \\
\text { combining or maybe members don't have } \\
\text { enough ability to do that }\end{array}$ & $\begin{array}{l}\text { Members of organization can't combine two } \\
\text { resource of explicit knowledge in one }\end{array}$ \\
\hline & $\begin{array}{l}\text { People consumes explicit knowledge by } \\
\text { reading/ viewing/ hearing from the media it } \\
\text { was externalized (explicit to tacit) }\end{array}$ & $\begin{array}{l}\text { Sometimes sources which members are using for } \\
\text { reading isn't enough or some members can't translate } \\
\text { it to tacit in an innovative way }\end{array}$ & $\begin{array}{l}\text { Members don't use any explicit knowledge } \\
\text { AND Members don't know after consuming } \\
\text { explicit knowledge how to translate it to tacit }\end{array}$ \\
\hline purce: Gol & ld et al. (2001); Wei (2008); Fan et al., (2008) a & and Nonaka and Takeuchi (1995) & \\
\hline le $5: \mathrm{Ru}$ & natrix & & \\
\hline & Very high & Medium & Very high \\
\hline Application & $\begin{array}{l}\text { For applying knowledge, organization } \\
\text { must integrate knowledge repositories } \\
\text { (e.g., codified and formulized content } \\
\text { for storage in databases) (e.g., a recording } \\
\text { of a manager's talk or lecturer's advices } \\
\text { for writing papers in high-impact factor) }\end{array}$ & $\begin{array}{l}\text { Members integrate knowledge repositories but } \\
\text { sometimes loose external knowledge or } \\
\text { internal knowledge }\end{array}$ & $\begin{array}{l}\text { Organization misses all knowledge warehouses } \\
\text { because don't try to integrate knowledge }\end{array}$ \\
\hline & $\begin{array}{l}\text { For applying knowledge, organization } \\
\text { must be interactive (means to allow the } \\
\text { integration and possible capture, analysis } \\
\text { or even explication of tacit knowledge } \\
\text { of the system's users) }\end{array}$ & $\begin{array}{l}\text { Enabling weak interaction among people and } \\
\text { providing a basic channel for sharing tacit } \\
\text { knowledge is done by organization }\end{array}$ & $\begin{array}{l}\text { Organization chooses IT components to apply } \\
\text { knowledge (Search, retrieval, and storage tools } \\
\text { to help organize and classify both formal and } \\
\text { informal knowledge.) }\end{array}$ \\
\hline & $\begin{array}{l}\text { Organization allow people to learn from } \\
\text { past decisions, both good and bad, and } \\
\text { past knowledge that can apply the lessons } \\
\text { learned to complex choices and } \\
\text { future decisions }\end{array}$ & $\begin{array}{l}\text { Sometimes happen within organization that } \\
\text { little documents which is related to past } \\
\text { decisions, both good and bad, and past } \\
\text { knowledge is not accessible }\end{array}$ & $\begin{array}{l}\text { Members don't know how to use past } \\
\text { decisions, experience, successes, and failures } \\
\text { which can help them to create and } \\
\text { apply knowledge }\end{array}$ \\
\hline & $\begin{array}{l}\text { Organization doesn't enable interaction } \\
\text { among people and providing a basic } \\
\text { channel for sharing tacit knowledge }\end{array}$ & $\begin{array}{l}\text { Organization chooses IT components but } \\
\text { they aren't newest one }\end{array}$ & $\begin{array}{l}\text { IT components isn't used within the } \\
\text { organization }\end{array}$ \\
\hline Source: Gol & ld et al. (2001) and Fan et al. (2008) & & \\
\hline Table 6: R & IOHC Inatis or piot & & \\
\hline & Very high & Medium & Very low \\
\hline Protection & $\begin{array}{l}\text { Organizations have training program to } \\
\text { teach an organizational members what is } \\
\text { acceptable behavior in terms of using } \\
\text { knowledge of organization }\end{array}$ & $\begin{array}{l}\text { Organization doesn't control training programs } \\
\text { at regular intervals to keep members updated to } \\
\text { changes in policies and procedures }\end{array}$ & $\begin{array}{l}\text { Members aren't familiar with mission and } \\
\text { goals of organization and Members don't } \\
\text { know which behavior is acceptable }\end{array}$ \\
\hline & $\begin{array}{l}\text { Organization develop teams to monitor, } \\
\text { check, and enforce security practices }\end{array}$ & $\begin{array}{l}\text { Sometimes team isn't active and authorized } \\
\text { processes, activities, and behaviors } \\
\text { are be conducted wrongly }\end{array}$ & $\begin{array}{l}\text { There is no team to check and control threats } \\
\text { that is following organizations }\end{array}$ \\
\hline & $\begin{array}{l}\text { Organization has procedures in place to } \\
\text { secure knowledge devices and } \\
\text { communication equipments. }\end{array}$ & $\begin{array}{l}\text { Knowledge devices and communication } \\
\text { equipments are not secure with best facilities }\end{array}$ & $\begin{array}{l}\text { There is no procedures to secure knowledge } \\
\text { and sometimes unauthorized knowledge is } \\
\text { communicated over an unauthorized channel }\end{array}$ \\
\hline & $\begin{array}{l}\text { All members must be held accountable for } \\
\text { any breaches to security that may result } \\
\text { from their negligence in organization }\end{array}$ & $\begin{array}{l}\text { Responsibility of members about their } \\
\text { negligence of security in organizations isn't very t } \\
\text { high, they are accountable but not in all situations }\end{array}$ & $\begin{array}{l}\text { Members are not accountable for } \\
\text { their breaches }\end{array}$ \\
\hline & $\begin{array}{l}\text { Organization upgrades and updates to } \\
\text { security procedures must occur in a } \\
\text { proactive rather than a reactive manner }\end{array}$ & $\begin{array}{l}\text { Upgrades and updates to security procedures } \\
\text { occur through the organization but sometimes } \\
\text { there is delay in updating and upgrading }\end{array}$ & $\begin{array}{l}\text { Upgrade and update of security don't } \\
\text { happen on time at all }\end{array}$ \\
\hline
\end{tabular}

Source: Gold et al. (2001)

\section{DISCUSSION}

Evaluation of KMC is one of the main objectives in each organization and also the accuracy of this evaluation is very important. All mathematical models (Fan et al., 2008, Zheng and $\mathrm{Hu}$, 2009) for KMC evaluation, focus on numerical variables as input data and relay on mathematical formulas. Existing models try to make this evaluation very precise by modifying mathematics models. The input data of these models usually is collected according to opinions of a number of experts. The aim of this study is to make the input data much accurate by considering the rubric matrix. In this rubric all attributes with specified characteristics is 
considered. Therefore it makes people's opinion (input data) very precise before applying the fuzzy linguistic method.

\section{CONCLUSION}

In this study a rubric matrix is introduced for attributes of KMC in fuzzy linguistic method. The proposed rubric makes the evaluation of capabilities (seven attributes) more easy and precise. It is appropriate for all organizations especially for situations which don't have experts in knowledge fields. The rubric with fuzzy linguistic method, which is used to evaluate the degree of KMC of organizations, is very useful in knowledge management initiatives and result will be more accurate. If the degree of KMC is too low according to the evaluation results, it has to be improved until reaches the acceptable status.

\section{REFERENCES}

Baimin, S., D. Feng and Z. Zhenggang, 2008. The fuzzy evaluation on enterprise knowledge management capability based on knowledge audit. Proceedings of the IEEE International Conference on Service Operations and Logistics, and Informatics, Oct. 12-15, IEEE Xplore Press, Beijing, pp: 792-796. DOI: 10.1109/SOLI.2008.4686506

Cavaleri, S.A., 2004. Leveraging organizational learning for knowledge and performance. Learn. Organ., 11 : 159-176. $10.1108 / 09696470410521619$

Chuang, S.H., 2004. A resource-based perspective on knowledge management capability and competitive advantage: An empirical investigation. Expert Syst. Appli., 27: 459-465. DOI: 10.1016/j.eswa.2004.05.008

Darroch, J., 2003. Developing a measure of knowledge management behaviors and practices. J. Knowl. Manage., 7: 41-54. DOI: 10.1108/13673270310505377

Fan, Z., B. Feng, Y. Sun and W. Ou, 2008. Evaluating knowledge management capability of organizations: A fuzzy linguistic method. Expert Syst. Appli., 36: 3346-3354. DOI: 10.1016/j.eswa.2008.01.052

Gold, A.H., A. Malhotra, and A.H. Segars, 2001. Knowledge management: An organizational capabilities perspective. J. Manage. Inform. Syst., 18: $185-214$.

Hitt, M.A., R.D. Ireland and H. Lee, 2000. Technological learning, knowledge management, firm growth and performance: An introductory essay. J. Eng. Technol. Manage., 17: 231-246. DOI: $10.1016 / \mathrm{S} 0923-4748(00) 00024-2$
Hylton, A., 2002. A KM initiative is unlikely to succeed without a knowledge audit.

Jabar, M.A., F. Sidi and M.H. Selamat, 2010. Tacit knowledge codification. J. Comput. Sci., 6: 11701176. DOI: $10.3844 /$ jcssp.2010.1170.1176

Kimber, K., H. Pillay and C. Richards, 2007. Technoliteracy and learning: An analysis of the quality of knowledge in electronic representations of understanding. Comput. Educ., 48: 59-79. DOI: 10.1016/j.compedu.2005.01.004

Morrison, J. and O.R.L. Sheng, 1992. Communication technologies and collaboration systems: Common domains, problems and solutions. J. Inform. Manage., 23: 93-112. DOI: 10.1016/03787206(92)90012-5

Niess, M.L., 2005. Preparing teachers to teach science and mathematics with technology: Developing a technology pedagogical content knowledge. Teach. Teacher Educ., 21: 509-523. DOI: 10.1016/j.tate.2005.03.006

Nonaka, I. and H. Takeuchi, 1995. The KnowledgeCreating Company: How Japanese Companies Create the Dynamics of Innovation. 1st Edn., Oxford University Press, New York, ISBN: 0195092694, pp: 284.

Sher, P.J. and V.C. Lee, 2004. Information technology as a facilitator for enhancing dynamic capabilities through knowledge management. Inform. Manage., 41: 933-945. DOI: 10.1016/j.im.2003.06.004

Wei, F., K. Hama, Y. Kotake, X. Lu and K. Mori, 2009. Autonomous collaboration technology in resource provision and utilization community. Proceedings of the International Symposium on Autonomous Decentralized Systems, Mar. 23-25, IEEE Xplore Press, Athens, pp: 1-7. DOI: 10.1109/ISADS.2009.5207365

Wei, L., 2008. Impact of popular organizational culture on knowledge creation. Proceedings of the 4th International Conference on Wireless Communications, Networking and Mobile Computing, Oct. 12-14, IEEE Xplore Press, Dalian, pp: 1-5. DOI: 10.1109/WiCom.2008.1383

Zhang, D., A. Wulamu, L. Gao and P. Shan, 2008. Analysis on interactive structure of knowledge acquisition. Proceedings of the International Symposium on Information Science and Engineering, Dec. 20-22, IEEE Xplore Press, Shanghai, pp: 654-658. DOI: 10.1109/ISISE.2008.328

Zheng, W. and Y. Hu, 2009. Grey evaluation method of knowledge management capability. Proceedings of the Second International Workshop on Knowledge Discovery and Data Mining, Jan. 23-25, IEEE Xplore Press, Moscow, pp: 256-260. DOI: 10.1109/WKDD.2009.205 